\title{
Application of silicon fertilizer affects nutritional quality of rice
}

Qihua Liu ${ }^{1}$, Xuebiao Zhou ${ }^{1 *}$, and Zhaowen Sun ${ }^{1}$

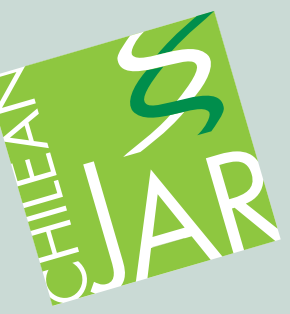

\section{ABSTRACT}

To date, information regarding the effects of $\mathrm{Si}$ on rice (Oryza sativa L.) nutritional quality is rarely reported. The current study was conducted to evaluate how Si fertilizer impacts the mineral element, protein and amino acid concentrations in brown and milled rice. The experiment was a randomized complete split-plot design, with Si treatments as main plot and two cultivars as subplot. Compared with the control, application of Si fertilizer significantly enhanced the $\mathrm{Zn}, \mathrm{Ca}$ and $\mathrm{Mg}$ concentrations in brown and milled rice but had nonsignificant effects on the $\mathrm{Fe}, \mathrm{Mn}$ and $\mathrm{Cu}$ concentrations. Moreover, application of Si fertilizer resulted in significant increases in the concentrations of protein and most of the amino acids in brown and milled rice. However, the Gly, His, Val, Met and Lys concentrations were unaffected by the application of Si. The responses of the Cys and Phe concentrations to Si fertilizer application were cultivar-dependent. Applying $\mathrm{Si}$ significantly increased $\mathrm{Zn}, \mathrm{Ca}, \mathrm{Mg}$ and protein concentrations by $21.77 \%, 25.77 \%, 7.25 \%$ and $6.19 \%$ in milled rice and by $25.18 \%, 39.81 \%, 9.24 \%$ and $5.52 \%$ in brown rice. These results indicate that $\mathrm{Si}$ fertilizer could improve rice nutritional quality by increasing concentrations of mineral elements, protein and some amino acids in brown and milled rice.

Key words: Nutritional quality, Oryza sativa, silicon.

${ }^{1}$ Rice Research Institute, Shandong Academy of Agricultural Sciences, Jinan, 250100, China.

"Corresponding author (1qhcj79@163.com).

Received: 6 October 2016.

Accepted: 4 April 2017.

doi:10.4067/S0718-58392017000200163

\section{INTRODUCTION}

In general, mineral elements, such as $\mathrm{Fe}, \mathrm{Cu}, \mathrm{Mn}, \mathrm{Zn}, \mathrm{Ca}$ and $\mathrm{Mg}$, are indispensable to the human body as they play important roles in controlling immunological function in adults and intelligence development in children (Belder et al., 2005; Boonchuay et al., 2013). Insufficient intake of these mineral elements from food results in the impairment of human health, such as the occurrence of anemia (Shan, 2006). It has been reported that approximately one-third of the world's population suffers from $\mathrm{Fe}$ and $\mathrm{Zn}$ malnutrition, a problem that is particularly severe in developing countries (Boonchuay et al., 2013). As a staple cereal crop, rice (Oryza sativa L.) provides not only carbohydrates but also protein, vitamin and mineral nutrition for more than half of the world's population. Therefore, efforts should be made to enhance the mineral element concentrations in milled rice in rice-consuming countries, particularly those that are also developing countries.

Previous studies have demonstrated that some mineral elements are abundant in the rice aleurone layer and embryo but less so in the endosperm (Bouis and Welch, 2010; Wei, et al., 2012a). Unfortunately the form of rice most commonly globally consumed is milled rice, which endosperm with the aleurone layer and embryo removed. Milled rice is rich in starch but lacks adequate nutritional components such as $\mathrm{Fe}$ and $\mathrm{Zn}$ (Bouis and Welch, 2010). It is well known that the concentrations of mineral elements in milled rice are determined by both genotype and cultivation conditions, such as climate, fertilizer, and water conditions (Yang et al., 1998; E et al., 2005; Yuan et al., 2006). Therefore, it is important to ameliorate the mineral concentrations in milled rice through breeding programs and agronomic approaches. Some screening studies have identified Fe- and Zndense genotypes with the aim of enhancing the mineral nutrition concentrations in milled rice (Sperotto et al., 2012; Wei et al., 2012a). Previous studies have also investigated the effects of fertilizer on the mineral element concentrations in milled rice, including the effects of fertilizer type, application pattern and application amount (Zhang et al., 2007; Wei et al., 2012a; He et al., 2013). Yuan et al. (2006) reported that the optimal application of $\mathrm{N}$ fertilizer in paddy fields was instrumental in the accumulation of $\mathrm{Fe}, \mathrm{Cu}, \mathrm{Mn}, \mathrm{Zn}, \mathrm{Ca}$ and $\mathrm{Mg}$ in milled rice. E et al. (2005) found that an increase in the amount of $P$ fertilizer applied enhanced the $\mathrm{Mg}$ concentration in milled rice and that a rational application of $\mathrm{K}$ increased the accumulation of $\mathrm{Fe}, \mathrm{Zn}, \mathrm{Cu}$ and $\mathrm{Mn}$ in milled rice. Boonchuay et al. (2013) 
confirmed that the $\mathrm{Zn}$ concentration of rice grains could be effectively increased by foliar application of $\mathrm{ZnSO}_{4} \cdot 7 \mathrm{H}_{2} \mathrm{O}$ after flowering. Similar results were reported by Wei et al. (2012b), who found that $\mathrm{ZnSO}_{4}$ and $\mathrm{Zn}$-amino were highly effective foliar $\mathrm{Zn}$ forms for increasing the accumulation of $\mathrm{Zn}$ in milled rice. He et al. (2013) reported that foliar diethylenetriaminepentaacetic acid (DTPA)-Fe application increased cysteine and mineral concentrations, including $\mathrm{Fe}$, $\mathrm{Ca}, \mathrm{Cu}, \mathrm{Zn}$ and $\mathrm{Mn}$.

Since the positive effects of Si amendment on plant growth were established, the influences of $\mathrm{Si}$ on the development of rice plants have been extensively studied (Mitani et al., 2005; Nwugo and Huerta, 2008). Currently, $\mathrm{Si}$ is ranked as the fourth most important element for rice production in rice-growing countries of southeast Asia, following N, P and K (Gong et al., 2012). Silicon, which is mainly absorbed by the roots in the form of silicic acid $\left(\mathrm{H}_{4} \mathrm{SiO}_{4}\right)$ and is distributed extensively throughout rice plant tissues, can effectively stimulate the growth of rice plants (Hossain et al., 2002). Silicon contributes to the components of the tissue cell through its involvement in the regulation of physiochemical metabolism in rice plants (Hossain et al., 2002). Several beneficial effects of Si on plants have also been demonstrated, such as the enhancement of photosynthesis, grain yield and plant tolerance to biotic (plant diseases and pests) and abiotic stresses (e.g., physical injury, drought stress, high temperature stress and salt stress) (Ma, 2004; Chen et al., 2011; Kim et al., 2014). Furthermore, Si fertilizer can increase the milling and eating qualities of rice by increasing head rice yield and the breakdown value of the Rapid Viscosity Analysis (RVA) profile (Zhang et al., 2007). Considering the contribution of $\mathrm{Si}$ to rice grain yield and quality, $\mathrm{Si}$ is now considered as an important determinant in rice production (Gong et al., 2012; Meharg and Meharg, 2015). However, to the best of our knowledge, whether the application of Si can effectively improve the nutritional quality of rice is rarely reported, especially the changes in mineral elements, amino acid and protein concentrations of grains.

The objective of the present study was to evaluate the effect of Si fertilizer on the nutritional quality of milled rice, specifically in terms of the amino acid, protein, and mineral element (Fe, $\mathrm{Zn}, \mathrm{Cu}, \mathrm{Mn}, \mathrm{Mg}$ and $\mathrm{Ca}$ ) concentrations.

\section{MATERIALS AND METHODS}

\section{Field experiment and cultivation management}

The experiment was conducted at Jining Experimental Station (35 $57^{\prime}$ N, $117^{\circ} 36^{\prime}$ E) of Rice Research Institute, Shandong Academy of Agricultural Sciences, in 2013 and 2014. The soil type of the experimental site was typical clay loam. Measured chemical properties of the experimental soil prior to fertilizer were as follows: $\mathrm{pH} 7.8$, organic matter $23.55 \mathrm{~g} \mathrm{~kg}^{-1}$, total $\mathrm{N}$ $1.09 \mathrm{~g} \mathrm{~kg}^{-1}$, available $\mathrm{N} 54.29 \mathrm{mg} \mathrm{kg}^{-1}$, available P 40.63 $\mathrm{mg} \mathrm{kg}^{-1}$, available $\mathrm{K} 146.50 \mathrm{mg} \mathrm{kg}^{-1}$, and available $\mathrm{Si} 150 \mathrm{mg} \mathrm{kg}^{-1}$.
The experiment used a split-plot design with three replicates. The main plots were subjected to two different Si fertilizer application treatments (90 and $0 \mathrm{~kg} \mathrm{ha}^{-1}$ ). The sub-plot included two common local japonica rice cultivars, 'Shengdao14' and 'Huaidao11'. To avoid the movement of water and fertilizer between the two $\mathrm{Si}$ application treatments, the main plots were separated by a $50-\mathrm{cm}$-wide ridge with plastic film inserted into soil to a depth of $30 \mathrm{~cm}$. Liquid Si fertilizer $\left(80 \% \mathrm{H}_{4} \mathrm{SiO}_{4}\right.$, fertilizer limited corporation, Shandong, China) was applied twice by spraying to the surface of soil for corresponding plot at intervals of $5 \mathrm{~d}$, with the first application at rice booting stage.

Rice seeds were uniformly sown on May 18 and transplanted into a paddy field on June 26 in both study years. The size of each plot was $25.9 \mathrm{~m}^{2}$ with a row space of $30 \mathrm{~cm}$ and a hill distance of $12 \mathrm{~cm}$, with four seedlings per hill. Each plot received standard agronomic practices commonly performed in local production.

\section{Sample preparation}

Rice grains from each plot were harvested at maturity. Then, they were dehulled by a dehusker (made in Korea) to obtain brown rice and milled by a rice polisher (made in Korea) to obtain milled rice. Grains from each plot were divided, with half remaining brown and half being milled. Subsequently, the brown and milled rice samples were ground into powder using a flour mill, sieved through a 100-mesh sieve, and divided into test samples for the chemical assays.

\section{Chemical determination}

Assay of mineral element concentrations in brown and milled rice. Concentrations of mineral elements $\mathrm{Fe}$, $\mathrm{Cu}, \mathrm{Mn}, \mathrm{Zn}, \mathrm{Ca}$, and $\mathrm{Mg}$ were assayed according to the method of the National Standard of People's Republic of China (GB/T 5009.90, 2003; GB/T 5009.92, 2003) and the Standard of Ministry of Agriculture of People's Republic of China (NY-861-2004). An inductively Coupled Plasma Optical Emission Spectrometer (Optima 5300DV, Perkin Elmer, Waltham, Massachusetts USA) was used to determine the concentrations of mineral elements in samples.

\section{Determination of crude protein and amino acid concentrations in brown and milled rice}

The crude protein concentration was assayed using a nitrogen analyzer (AutoKjeldahl Unit K-370, Büchi Labortechnik, Flawil, Switzerland) according to Approved Method 46-30.01 (AACCI, 2010) using a N conversion factor of 5.95. A full-automatic amino acid analyzer (L8800, Hitachi Limited Corporation, Tokyo, Japan) was employed to measure the amino acid concentrations following the standard sample digestion method of the National Standard of People's Republic of China (GB7649-87, 1987). 


\section{Statistical analysis}

For all parameters, there were nonsignificant differences in data across 2 yr study and in interactions Years $\times$ Cultivars, Years $\times$ Treatments (Tables 1-7). Therefore, data were analyzed as the means over the 2 yr study using SPSS 11.5 (SPSS Inc., Chicago, Illinois, USA). The least significant difference (LSD) test was used to compare treatment with control means at the $p=0.05$ probability level. Relationships between the mineral element concentrations and the amino acid concentrations in milled rice were assessed using Pearson correlation analysis. Figures were plotted using Sigmaplot 10 (Systat Software, San Jose, California, USA).

\section{RESULTS AND DISCUSSION}

\section{The effects of Si fertilizer on mineral elements concentrations in brown and milled rice}

Silicon, the second most abundant element in soil, plays a crucial role in regulating plants development, particularly for Si-accumulator crops (Yamamoto et al., 2012; Meharg and Megarg, 2015). How Si fertilizer impacts mineral elements concentration in rice grains is still poorly understood. Accordingly, we investigated the relationship between the application of Si fertilizer and the changes in mineral elements of rice grains under field condition, which is of great significance. In the current study, Si fertilizer application significantly enhanced the $\mathrm{Zn}, \mathrm{Ca}$ and $\mathrm{Mg}$ concentrations in brown and milled rice for both cultivars but had no apparent effect on the $\mathrm{Fe}, \mathrm{Mn}$ and $\mathrm{Cu}$ concentrations in either (Figures 1 and 2). In 'Shengdao14', the application of $\mathrm{Si}$ fertilizer markedly increased the $\mathrm{Zn}, \mathrm{Ca}$ and $\mathrm{Mg}$ concentrations of milled rice by $32.97 \%$, $29.92 \%$ and $7.89 \%$, respectively. In 'Huaidao 11 ', Si application markedly increased the corresponding mineral elements by $10.56 \%, 21.61 \%$ and $6.61 \%$, respectively. Similar results were observed in brown rice (Figure 2). In 'Shengdao14', Si fertilizer markedly increased the Zn, Ca and $\mathrm{Mg}$ concentrations in brown rice by $29.17 \%, 45.08 \%$ and $9.17 \%$, respectively. In 'Huaidao11', the corresponding mineral elements were markedly increased by $21.18 \%$, $34.54 \%$ and $9.31 \%$, respectively. The results suggest that Si impacted the accumulation of other mineral elements in milled rice and that the effects were more pronounced in 'Shengdao 14' than in 'Huaidao11'.

Past report showed that the application of Si inhibited the absorption of $\mathrm{Fe}$ and $\mathrm{Mn}$, thereby leading to the significant reduction of $\mathrm{Fe}$ and $\mathrm{Mn}$ concentrations in rice plants (Islam and Saha, 1969). Interestingly, in the present study, the treatment of Si application did not exert significant influence on $\mathrm{Fe}$ and $\mathrm{Mn}$ concentrations of brown and milled rice when compared with control (Tables 2 and 3). We speculate that $\mathrm{Si}$ could alter the distribution ratio of $\mathrm{Fe}$ and $\mathrm{Zn}$ among different plant organs and promote their transportation to grains through phloem, which maybe the reason for the insignificant difference (Grusak, 1994; Xing and Zhang, 1998). Additionally, it is notable that the $\mathrm{Ca}$ and $\mathrm{Mg}$ concentrations in brown and milled rice were significantly enhanced after the application of Si fertilizer, suggesting the beneficial effect of $\mathrm{Si}$ on some mineral elements accumulation in rice. The result may be associated with the promotion in absorption of $\mathrm{Ca}$ and $\mathrm{Mg}$ elements in rice plants resulting from $\mathrm{Si}$ application (Islam and Saha, 1969). Moreover, the transportation and allocation mechanism of mineral element in rice under Si application should be further investigated in future, which can aid in fully understanding the function of $\mathrm{Si}$ for determining rice nutritional quality.

\section{The effects of Si fertilizer on protein and amino acids concentrations in brown and milled rice}

The protein and amino acids concentrations of milled rice are important parameters for evaluating the nutritional quality of rice; the concentrations of essential amino acids are particularly important as these amino acids cannot be synthesized by the human body (Wang et al., 2007). The protein in milled rice is more readily digested and absorbed by human body than is the protein of any other cereal. The biological value of protein in milled rice typically ranges from 74-75, which greatly exceeds the corresponding values for wheat and corn (Wang et al., 2007). As a result, milled rice has been identified as an excellent plant protein. It has been verified that, in addition to genotype, cultivation conditions are also pivotal factors affecting the protein and amino acid concentrations in milled rice (Yuan et al., 2006). Previous reports have shown that the optimal application of $\mathrm{N}$ fertilizer was beneficial for the increment of protein and amino acid concentrations in milled rice (Wang et al., 2001). Here, the application of Si fertilizer also significantly enhanced the protein concentration in milled rice, with increases of $7.29 \%$ and $5.08 \%$ in 'Shengdao14' and 'Huaidao11', respectively, relative to the control treatment. Similar tendency was observed in brown rice (Figure 3). The application of Si fertilizer markedly increased concentrations of most of the amino acids evaluated in milled rice for both cultivars, including nonessential (Asp, Glu, Ser, Ala, Tyr, Arg and Pro) and essential amino acids (Thr, Ile and Leu). Compared with the control

Table 1. $P$ values from the ANOVA of the main effects of cultivars, treatments, years, and their interactions on mineral elements concentrations in milled rice.

\begin{tabular}{lcccccc}
\hline \multirow{2}{*}{$\begin{array}{l}\text { Source of } \\
\text { variance }\end{array}$} & \multicolumn{6}{c}{ Mineral elements concentrations in milled rice } \\
\cline { 2 - 7 } & $\mathrm{Fe}$ & $\mathrm{Cu}$ & $\mathrm{Mn}$ & $\mathrm{Zn}$ & $\mathrm{Ca}$ & $\mathrm{Mg}$ \\
\hline Cultivar (C) & $p<0.01$ & $\mathrm{NS}$ & $p<0.05$ & $p<0.05$ & $p<0.05$ & $p<0.01$ \\
Treatment (T) & $\mathrm{NS}$ & $\mathrm{NS}$ & $\mathrm{NS}$ & $p<0.05$ & $p<0.05$ & $p<0.05$ \\
Year (Y) & $\mathrm{NS}$ & $\mathrm{NS}$ & $\mathrm{NS}$ & $\mathrm{NS}$ & $\mathrm{NS}$ & $\mathrm{NS}$ \\
$\mathrm{C} \times \mathrm{T}$ & $\mathrm{NS}$ & $\mathrm{NS}$ & $\mathrm{NS}$ & $\mathrm{NS}$ & $\mathrm{NS}$ & $p<0.05$ \\
$\mathrm{~T} \times \mathrm{Y}$ & $\mathrm{NS}$ & $\mathrm{NS}$ & $\mathrm{NS}$ & $\mathrm{NS}$ & $\mathrm{NS}$ & $\mathrm{NS}$ \\
$\mathrm{C} \times \mathrm{Y}$ & $\mathrm{NS}$ & $\mathrm{NS}$ & $\mathrm{NS}$ & $\mathrm{NS}$ & $\mathrm{NS}$ & $\mathrm{NS}$ \\
$\mathrm{C} \times \mathrm{T} \times \mathrm{Y}$ & $\mathrm{NS}$ & $\mathrm{NS}$ & $\mathrm{NS}$ & $\mathrm{NS}$ & $\mathrm{NS}$ & $\mathrm{NS}$ \\
\hline $\mathrm{NS}$ & &
\end{tabular}

NS: Nonsignificant difference at $p<0.05$ level. 
Figure. 1. Effects of Si fertilizer on mineral elements concentrations in milled rice.
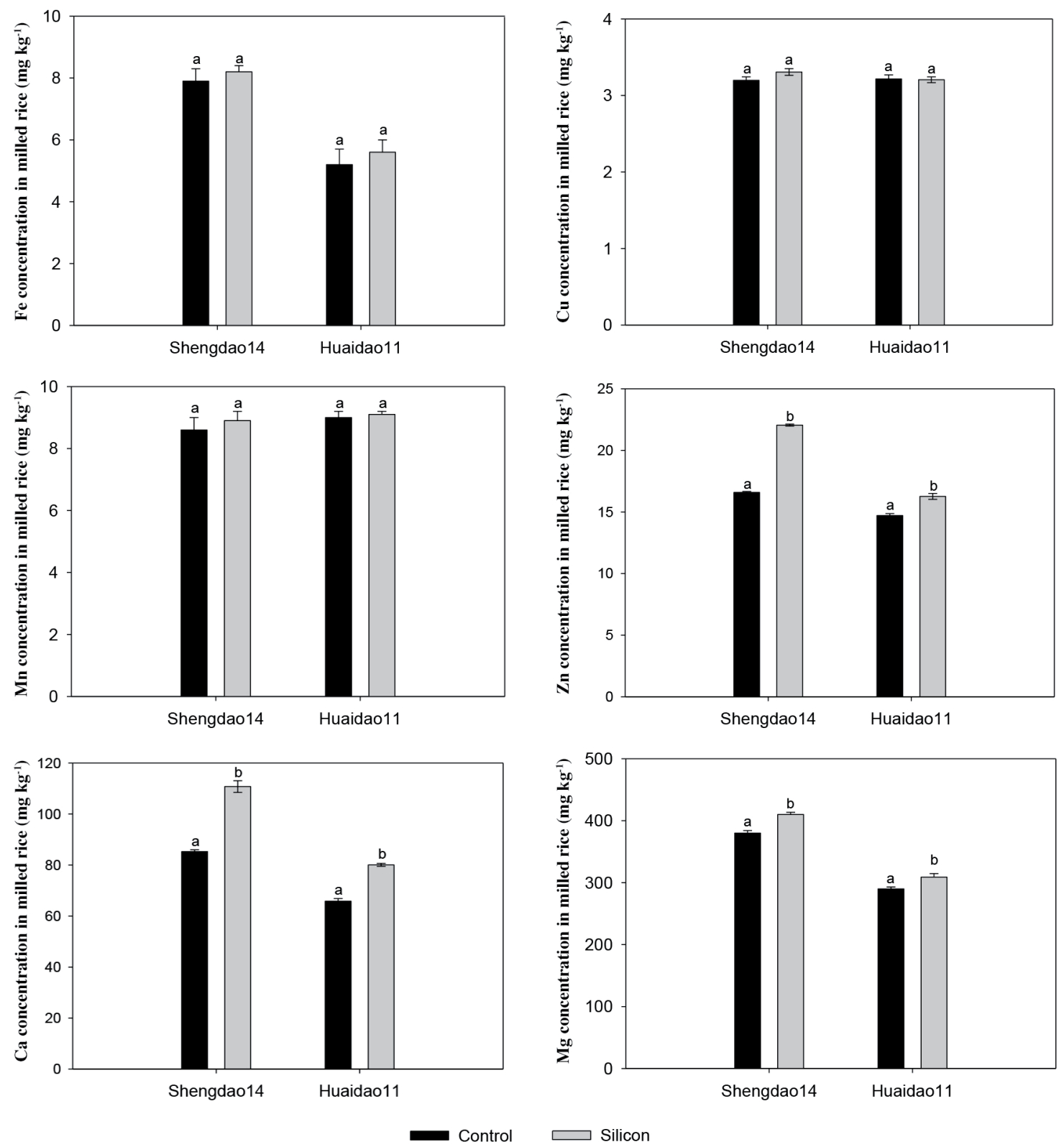

Different letters between treatments within the same cultivar indicate a significant difference at $p<0.05$.

treatment, the concentrations of Asp, Glu, Ser, Ala, Tyr, Arg, Pro, Thr, Ile, and Leu increased on average by $12.00 \%$, $3.55 \%, 9.15 \%, 5.06 \%, 28.77 \%, 13.24 \%, 10.83 \%, 11.50 \%$,

Table 2. $P$ values from the ANOVA of the main effects of cultivars, treatments, years, and their interactions on mineral elements concentrations in brown rice.

\begin{tabular}{lcllccc}
\hline \multirow{2}{*}{$\begin{array}{l}\text { Source of } \\
\text { variance }\end{array}$} & \multicolumn{5}{c}{ Mineral elements concentrations in brown rice } \\
\cline { 2 - 7 } & $\mathrm{Fe}$ & $\mathrm{Cu}$ & $\mathrm{Mn}$ & $\mathrm{Zn}$ & $\mathrm{Ca}$ & $\mathrm{Mg}$ \\
\hline Cultivar (C) & $p<0.05$ & $\mathrm{NS}$ & $\mathrm{NS}$ & $\mathrm{NS}$ & $p<0.01$ & $p<0.01$ \\
Treatment (T) & $\mathrm{NS}$ & $\mathrm{NS}$ & $\mathrm{NS}$ & $p<0.05$ & $p<0.05$ & $p<0.01$ \\
Year (Y) & $\mathrm{NS}$ & $\mathrm{NS}$ & $\mathrm{NS}$ & $\mathrm{NS}$ & $\mathrm{NS}$ & $\mathrm{NS}$ \\
$\mathrm{C} \times \mathrm{T}$ & $\mathrm{NS}$ & $\mathrm{NS}$ & $\mathrm{NS}$ & $\mathrm{NS}$ & $p<0.05$ & $p<0.05$ \\
$\mathrm{~T} \times \mathrm{Y}$ & $\mathrm{NS}$ & $\mathrm{NS}$ & $\mathrm{NS}$ & $\mathrm{NS}$ & $\mathrm{NS}$ & $\mathrm{NS}$ \\
$\mathrm{C} \times \mathrm{Y}$ & $\mathrm{NS}$ & $\mathrm{NS}$ & $\mathrm{NS}$ & $\mathrm{NS}$ & $\mathrm{NS}$ & $\mathrm{NS}$ \\
$\mathrm{C} \times \mathrm{T} \times \mathrm{Y}$ & $\mathrm{NS}$ & $\mathrm{NS}$ & $\mathrm{NS}$ & $\mathrm{NS}$ & $\mathrm{NS}$ & $\mathrm{NS}$ \\
\hline
\end{tabular}

NS: Nonsignificant difference at $p<0.05$ level.
$8.82 \%$ and $4.75 \%$, respectively, across both cultivars (Tables 4 and 5). The application of Si fertilizer also triggered significant increments in Asp, Glu, Ser, Ala, Tyr, Arg, Pro,

Table 3. $P$ values from the ANOVA of the main effects of cultivars, treatments, years, and their interactions on protein concentration in milled and brown rice.

\begin{tabular}{lcc}
\hline $\begin{array}{l}\text { Source of } \\
\text { variance }\end{array}$ & $\begin{array}{c}\text { Protein concentration } \\
\text { in milled rice }\end{array}$ & $\begin{array}{c}\text { Protein concentration } \\
\text { in brown rice }\end{array}$ \\
\hline Cultivar (C) & $p<0.05$ & $p<0.05$ \\
Treatment (T) & $p<0.05$ & $p<0.05$ \\
Year $(\mathrm{Y})$ & $\mathrm{NS}$ & $\mathrm{NS}$ \\
$\mathrm{C} \times \mathrm{T}$ & $\mathrm{NS}$ & $\mathrm{NS}$ \\
$\mathrm{T} \times \mathrm{Y}$ & $\mathrm{NS}$ & $\mathrm{NS}$ \\
$\mathrm{C} \times \mathrm{Y}$ & $\mathrm{NS}$ & $\mathrm{NS}$ \\
$\mathrm{C} \times \mathrm{T} \times \mathrm{Y}$ & $\mathrm{NS}$ & $\mathrm{NS}$
\end{tabular}

NS: Nonsignificant difference at $p<0.05$ level. 
Figure 2. Effects of Si fertilizer on mineral element concentrations in brown rice.
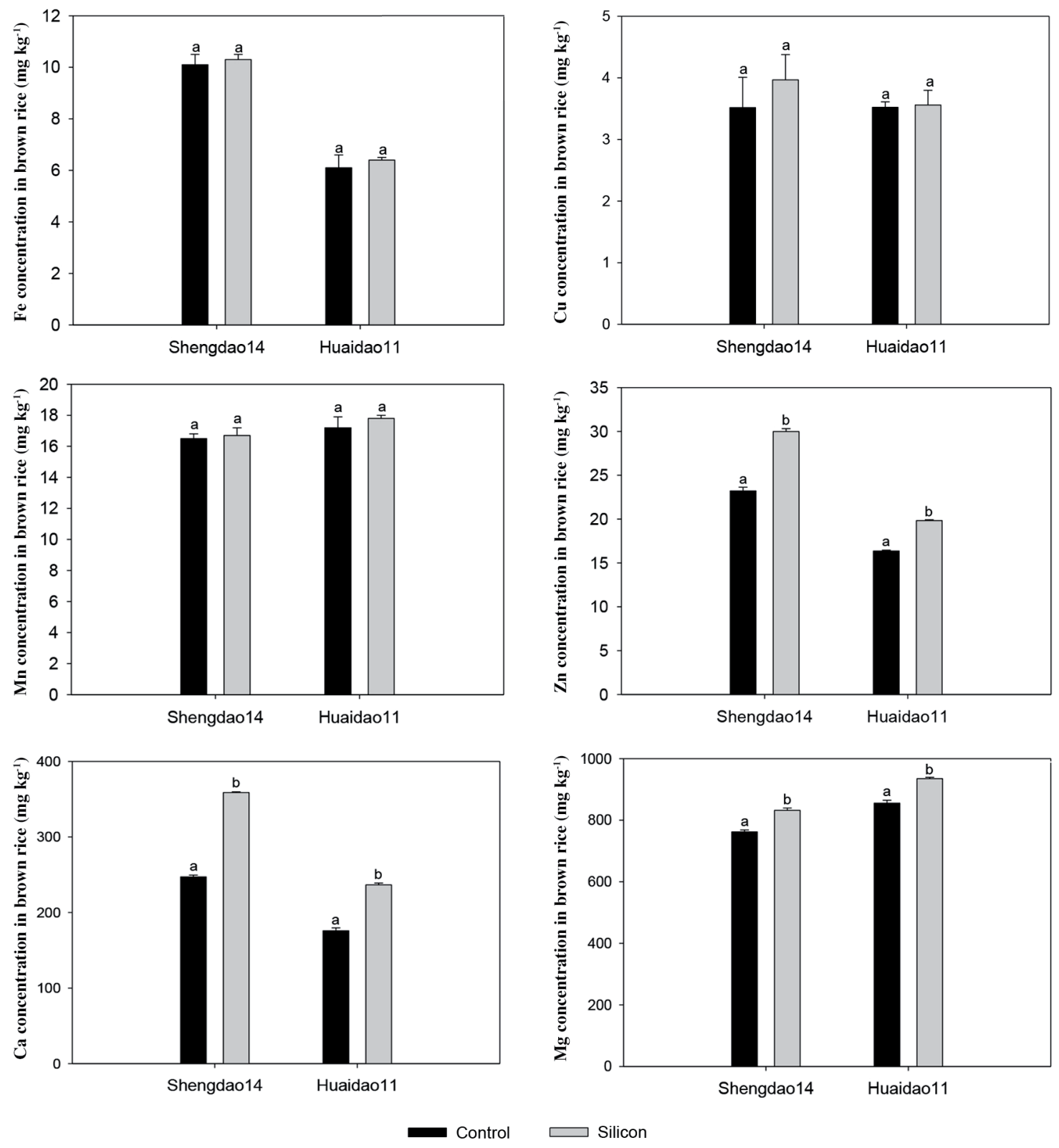

Different letters between treatments within the same cultivar indicate a significant difference at $p<0.05$.

Thr, Ile, and Leu contents of brown rice for both cultivars. They were averagely enhanced by $8.46 \%, 5.18 \%, 5.63 \%$, $4.02 \%, 11.91 \%, 8.79 \%, 16.24 \%, 6.35 \%, 10 \%$ and $7.04 \%$, respectively, across both cultivars (Tables 6 and 7). There was nonsignificant effect of the application of Si fertilizer on the Gly, His, Val, Met or Lys concentrations in milled and brown rice. Additionally, there were varietal differences in the responses of the Cys and Phe concentrations to Si fertilizer. Compared with the control treatment, Cys concentration of milled rice increased significantly by $44.44 \%$ in 'Shengdao14' but remained unchanged in 'Huaidao11'; in contrast, Phe concentration of milled rice was markedly enhanced by $14.63 \%$ in 'Huaidao11' but remained unaffected in 'Shengdao14'.
Our previous research reported that applying Si could significantly enhance rice grain yield (Liu et al., 2016). In general, the increase of grain yield is closely associated with the enhancement of starch accumulation, leading to decreased protein concentration in grain. However, in the present study, applying $\mathrm{Si}$ resulted in an increase in protein concentration in grain, which was possibility partly attributed to decreased amylose concentration in grain as reported by Zhang et al. (2007). Additionally, it has been well known that glutamic-pyruvic transaminase is an important enzyme being involved in amino acids and protein synthesis in rice grain (Miflim and Habash, 2002). Some reports demonstrated that the $\mathrm{N}$ concentration in rice grains was increased after applying $\mathrm{Si}$, due to the promotion 
Figure 3. Effect of Si fertilizer on protein concentration in brown and milled rice.
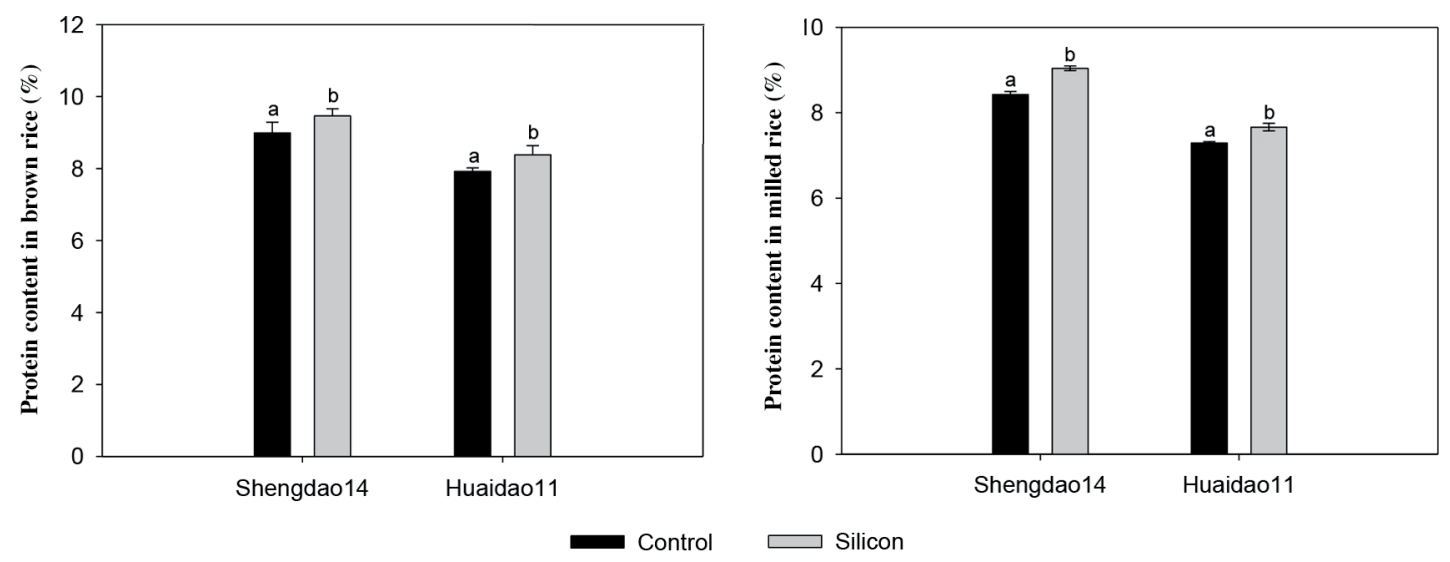

Different letters between treatments within the same cultivar indicate a significant difference at $p<0.05$.

Table 4. Effects of Si fertilizer on concentrations of non-essential amino acids in milled rice.

\begin{tabular}{|c|c|c|c|c|c|c|c|c|c|c|c|}
\hline \multirow[b]{2}{*}{ Cultivar } & \multirow[b]{2}{*}{ Treatment } & \multicolumn{10}{|c|}{ Non-essential amino acids concentrations in milled rice } \\
\hline & & Asp & Glu & Ser & Gly & Ala & Cys & Tyr & His & $\operatorname{Arg}$ & Pro \\
\hline \multirow[t]{2}{*}{ Shengdao14 } & Control & $0.79 \mathrm{a}$ & $1.52 \mathrm{a}$ & $0.41 \mathrm{a}$ & $0.37 \mathrm{a}$ & $0.45 \mathrm{a}$ & $0.09 \mathrm{a}$ & $0.19 \mathrm{a}$ & $0.21 \mathrm{a}$ & $0.58 \mathrm{a}$ & $0.30 \mathrm{a}$ \\
\hline & Silicon fertilizer & $0.88 \mathrm{~b}$ & $1.57 \mathrm{~b}$ & $0.44 \mathrm{~b}$ & $0.38 \mathrm{a}$ & $0.47 \mathrm{~b}$ & $0.13 b$ & $0.23 b$ & $0.24 \mathrm{a}$ & $0.66 \mathrm{~b}$ & $0.34 \mathrm{~b}$ \\
\hline \multirow{2}{*}{ Huaidao11 } & Control & $0.71 \mathrm{a}$ & $1.30 \mathrm{a}$ & $0.36 \mathrm{a}$ & $0.33 a$ & $0.34 \mathrm{a}$ & $0.11 \mathrm{a}$ & $0.18 \mathrm{a}$ & $0.22 \mathrm{a}$ & $0.52 \mathrm{a}$ & $0.30 \mathrm{a}$ \\
\hline & Silicon fertilizer & $\begin{array}{c}0.80 \mathrm{~b} \\
p \text { value }\end{array}$ & $1.35 b$ & $0.40 \mathrm{~b}$ & $0.36 \mathrm{a}$ & $0.36 \mathrm{~b}$ & $0.10 \mathrm{a}$ & $0.24 b$ & $0.20 \mathrm{a}$ & $0.58 \mathrm{~b}$ & $0.33 b$ \\
\hline Cultivar $(\mathrm{C})$ & & NS & NS & NS & NS & $p<0.05$ & NS & NS & NS & $p<0.05$ & NS \\
\hline Treatment $(\mathrm{T})$ & & $p<0.05$ & $p<0.05$ & $p<0.01$ & NS & $p<0.05$ & $p<0.05$ & $p<0.05$ & NS & $p<0.01$ & $p<0.01$ \\
\hline Year $(\mathrm{Y})$ & & NS & NS & NS & NS & NS & NS & NS & NS & NS & NS \\
\hline $\mathrm{C} \times \mathrm{T}$ & & NS & NS & NS & NS & NS & $p<0.05$ & NS & NS & $p<0.05$ & NS \\
\hline $\mathrm{T} \times \mathrm{Y}$ & & NS & NS & NS & NS & NS & NS & NS & NS & NS & NS \\
\hline $\mathrm{C} \times \mathrm{Y}$ & & NS & NS & NS & NS & NS & NS & NS & NS & NS & NS \\
\hline $\mathrm{C} \times \mathrm{T} \times \mathrm{Y}$ & & NS & NS & NS & NS & NS & NS & NS & NS & NS & NS \\
\hline
\end{tabular}

Different letters between treatments within the same cultivar indicate a significant difference at $p<0.05$.

NS: Nonsignificant difference at $p<0.05$ level.

Asp: Asparagine, Glu: glutamic acid, Ser: serine, Gly: glycine, Ala: alanine, Cys: cysteine, Tyr: tyrosine, His: histidine, Arg: arginine, Pro: proline.

Table 5. Effects of Si fertilizer on concentrations of essential amino acids in milled rice.

\begin{tabular}{|c|c|c|c|c|c|c|c|c|}
\hline \multirow[b]{2}{*}{ Cultivar } & \multirow[b]{2}{*}{ Treatment } & \multicolumn{7}{|c|}{ Essential amino acids concentrations in milled rice } \\
\hline & & Thr & Val & Met & Ile & Leu & Phe & Lys \\
\hline \multirow[t]{2}{*}{ Shengdao14 } & Control & $0.29 \mathrm{a}$ & $0.45 \mathrm{a}$ & $0.09 \mathrm{a}$ & $0.34 \mathrm{a}$ & $0.73 \mathrm{a}$ & $0.50 \mathrm{a}$ & $0.29 \mathrm{a}$ \\
\hline & Si fertilizer & $0.33 b$ & $0.46 \mathrm{a}$ & $0.09 \mathrm{a}$ & $0.38 \mathrm{~b}$ & $0.75 b$ & $0.48 \mathrm{a}$ & $0.31 \mathrm{a}$ \\
\hline \multirow[t]{2}{*}{ Huaidao11 } & Control & $0.28 \mathrm{a}$ & $0.53 \mathrm{a}$ & $0.14 \mathrm{a}$ & $0.34 \mathrm{a}$ & $0.64 \mathrm{a}$ & $0.41 \mathrm{a}$ & $0.31 \mathrm{a}$ \\
\hline & Si fertilizer & $0.30 \mathrm{~b}$ & $0.53 \mathrm{a}$ & $0.15 \mathrm{a}$ & $0.36 \mathrm{~b}$ & $0.69 b$ & $0.47 \mathrm{~b}$ & $0.28 \mathrm{a}$ \\
\hline Multiple ANOVA & & $p$ value & & & & & & \\
\hline Cultivar (C) & & NS & $p<0.05$ & NS & NS & $p<0.05$ & NS & NS \\
\hline Treatment (T) & & $p<0.05$ & NS & NS & $p<0.05$ & $p<0.05$ & $p<0.05$ & NS \\
\hline Year $(\mathrm{Y})$ & & NS & NS & NS & NS & NS & NS & NS \\
\hline $\mathrm{C} \times \mathrm{T}$ & & NS & NS & NS & NS & NS & $p<0.05$ & NS \\
\hline $\mathrm{T} \times \mathrm{Y}$ & & NS & NS & NS & NS & NS & NS & NS \\
\hline $\mathrm{C} \times \mathrm{Y}$ & & NS & NS & NS & NS & NS & NS & NS \\
\hline $\mathrm{C} \times \mathrm{T} \times \mathrm{Y}$ & & NS & NS & NS & NS & NS & NS & NS \\
\hline
\end{tabular}

Different letters between treatments within the same cultivar indicate a significant difference at $p<0.05$.

NS: Nonsignificant difference at $p<0.05$ level.

Thr: Threonine, Val: valine, Met: methionine, Ile: isoleucine, Leu: leucine, Phe: phenylalanine, Lys: lysine.

of transportation efficiency of $\mathrm{N}$ from leaves to grains induced by the enhancement of the activity of glutamicpyruvic transaminase in rice leaves (Jiang et al., 2004; Pati et al., 2016). These results better explain the observed increases in most amino acids and protein concentrations in milled rice in the present study. Nevertheless, when compared the control, part amino acids concentration in grain remained unchanged under Si treatment, which still needs further research especially for related mechanism. 
Table 6. Effects of Si fertilizer on concentrations of non-essential amino acids in brown rice.

\begin{tabular}{|c|c|c|c|c|c|c|c|c|c|c|c|}
\hline \multirow[b]{2}{*}{ Cultivar } & \multirow[b]{2}{*}{ Treatment } & \multicolumn{10}{|c|}{ Non-essential amino acids concentrations in brown rice } \\
\hline & & Asp & Glu & Ser & Gly & Ala & Cys & Tyr & His & $\operatorname{Arg}$ & Pro \\
\hline \multirow[t]{2}{*}{ Shengdao14 } & Control & $0.81 \mathrm{a}$ & $1.67 \mathrm{a}$ & $0.48 \mathrm{a}$ & $0.40 \mathrm{a}$ & $0.59 \mathrm{a}$ & $0.08 \mathrm{a}$ & $0.21 \mathrm{a}$ & $0.20 \mathrm{a}$ & $0.64 \mathrm{a}$ & $0.36 \mathrm{a}$ \\
\hline & Si fertilizer & $0.89 \mathrm{~b}$ & $1.73 \mathrm{~b}$ & $0.51 \mathrm{~b}$ & $0.41 \mathrm{a}$ & $0.61 \mathrm{~b}$ & $0.12 b$ & $0.23 b$ & $0.24 \mathrm{a}$ & $0.73 b$ & $0.44 \mathrm{~b}$ \\
\hline \multirow{2}{*}{ Huaidao11 } & Control & $0.71 \mathrm{a}$ & $1.48 \mathrm{a}$ & $0.40 \mathrm{a}$ & $0.35 \mathrm{a}$ & $0.43 \mathrm{a}$ & $0.07 \mathrm{a}$ & $0.21 \mathrm{a}$ & $0.19 \mathrm{a}$ & $0.57 \mathrm{a}$ & $0.39 \mathrm{a}$ \\
\hline & Si fertilizer & $0.76 \mathrm{~b}$ & $1.58 \mathrm{~b}$ & $0.42 b$ & $0.37 \mathrm{a}$ & $0.45 b$ & $0.08 \mathrm{a}$ & $0.24 b$ & $0.20 \mathrm{a}$ & $0.59 \mathrm{~b}$ & $0.43 b$ \\
\hline Multiple ANOVA & & $p$ value & & & & & & & & & \\
\hline Cultivar (C) & & $p<0.05$ & NS & NS & NS & $p<0.05$ & NS & NS & NS & $p<0.05$ & NS \\
\hline Treatment (T) & & $p<0.05$ & $p<0.05$ & $p<0.01$ & NS & $p<0.05$ & $p<0.05$ & $p<0.05$ & NS & $p<0.01$ & $p<0.01$ \\
\hline Year $(\mathrm{Y})$ & & NS & NS & NS & NS & NS & NS & NS & NS & NS & NS \\
\hline $\mathrm{C} \times \mathrm{T}$ & & NS & NS & NS & NS & NS & $p<0.05$ & NS & NS & $p<0.05$ & NS \\
\hline $\mathrm{T} \times \mathrm{Y}$ & & NS & NS & NS & NS & NS & NS & NS & NS & NS & NS \\
\hline $\mathrm{C} \times \mathrm{Y}$ & & NS & NS & NS & NS & NS & NS & NS & NS & NS & NS \\
\hline $\mathrm{C} \times \mathrm{T} \times \mathrm{Y}$ & & NS & NS & NS & NS & NS & NS & NS & NS & NS & NS \\
\hline
\end{tabular}

Different letters between treatments within the same cultivar indicate a significant difference at $p<0.05$.

NS: Nonsignificant difference at $p<0.05$ level.

Asp: Asparagine, Glu: glutamic acid, Ser: serine, Gly: glycine, Ala: alanine, Cys: cysteine, Tyr: tyrosine, His: histidine, Arg: arginine, Pro: proline.

Table 7. Effects of Si fertilizer on concentrations of essential amino acids in brown rice.

\begin{tabular}{|c|c|c|c|c|c|c|c|c|}
\hline \multirow[b]{2}{*}{ Cultivar } & \multirow[b]{2}{*}{ Treatment } & \multicolumn{7}{|c|}{ Essential amino acids concentrations in brown rice } \\
\hline & & Thr & Val & Met & Ile & Leu & Phe & Lys \\
\hline \multirow[t]{2}{*}{ Shengdao14 } & Control & $0.32 \mathrm{a}$ & $0.49 \mathrm{a}$ & $0.11 \mathrm{a}$ & $0.35 \mathrm{a}$ & $0.78 \mathrm{a}$ & $0.52 \mathrm{a}$ & $0.31 \mathrm{a}$ \\
\hline & Si fertilizer & $0.35 b$ & $0.50 \mathrm{a}$ & $0.10 \mathrm{a}$ & $0.40 \mathrm{~b}$ & $0.82 b$ & $0.49 \mathrm{a}$ & $0.33 \mathrm{a}$ \\
\hline \multirow[t]{2}{*}{ Huaidao11 } & Control & $0.30 \mathrm{a}$ & $0.57 \mathrm{a}$ & $0.15 \mathrm{a}$ & $0.35 \mathrm{a}$ & $0.67 \mathrm{a}$ & $0.40 \mathrm{a}$ & $0.33 \mathrm{a}$ \\
\hline & Si fertilizer & $0.31 \mathrm{~b}$ & $0.61 \mathrm{a}$ & $0.21 \mathrm{a}$ & $0.37 \mathrm{~b}$ & $0.73 b$ & $0.46 \mathrm{~b}$ & $0.31 \mathrm{a}$ \\
\hline Multiple ANOVA & & $p$ value & & & & & & \\
\hline Cultivar (C) & & NS & $p<0.01$ & NS & NS & $p<0.05$ & NS & NS \\
\hline Treatment (T) & & $p<0.05$ & NS & NS & $p<0.05$ & $p<0.01$ & $p<0.05$ & NS \\
\hline Year (Y) & & NS & NS & NS & NS & NS & NS & NS \\
\hline $\mathrm{C} \times \mathrm{T}$ & & NS & NS & NS & NS & NS & $p<0.05$ & NS \\
\hline $\mathrm{T} \times \mathrm{Y}$ & & NS & NS & NS & NS & NS & NS & NS \\
\hline $\mathrm{C} \times \mathrm{Y}$ & & NS & NS & NS & NS & NS & NS & NS \\
\hline $\mathrm{C} \times \mathrm{T} \times \mathrm{Y}$ & & NS & NS & NS & NS & NS & NS & NS \\
\hline
\end{tabular}

Different letters between treatments within the same cultivar indicate a significant difference at $p<0.05$.

NS: Nonsignificant difference at $p<0.05$ level.

Thr: Threonine, Val: valine, Met: methionine, Ile: isoleucine, Leu: leucine, Phe: phenylalanine, Lys: lysine.

\section{CONCLUSION}

A 2-yr field experiment was conducted to investigate the effects of Si fertilizer on the mineral elements, protein and amino acids concentrations in brown and milled rice. We observed that, in comparison with control, the application of $\mathrm{Si}$ at the rice booting stage increased the $\mathrm{Zn}, \mathrm{Ca}, \mathrm{Mg}$ and protein concentrations and the most of the amino acids concentrations, including Asp, Glu, Ser, Ala, Tyr, Arg, Pro, $\mathrm{Thr}$, Ile and Leu in brown and milled rice. However, Si application did not exhibit effects on the concentrations of Gly, His, Val, Met and Lys in milled rice. Applying Si fertilizer could ameliorate the nutritional quality of rice, which will provide beneficial reference for guiding application of Si fertilizer in high-quality rice production.

\section{ACKNOWLEDGEMENTS}

The research work was financially supported by Innovation project of Vital Applied Agriculture Technology in Shandong.

\section{REFERENCES}

AACCI. 2010. Approved methods of analysis. $11^{\text {th }}$ ed. Methods 46-30.01, 61-02.01. Available online only. American Association of Cereal Chemists International (AACCI), St. Paul, Minnesota, USA.

Belder, P., Spiertz, J.H.J., Bouman, B.A.M., Lu, G., and Tuong, T.P. 2005. Nitrogen economy and water productivity of lowland rice under water-saving irrigation. Field Crops Research 93:169-185.

Boonchuay, P., Cakmak, I., Rerkasem, B., and Promuthai, C. 2013. Effect of different foliar zinc application at different growth stages on seed zinc concentration and its impact on seedling vigor in rice. Soil Science and Plant Nutrition 59:180-188.

Bouis, H.E., and Welch, R.M. 2010. Biofortification-A sustainable agricultural strategy for reducing micronutrient malnutrition in the global south. Crop Science 50:S-20-S-32.

Chen, W., Yao, X.Q., Cai, K.Z., and Chen, J.N. 2011. Silicon alleviates drought stress of rice plants by improving plant water status, photosynthesis and mineral nutrient absorption. Biological Trace Element Research 142:67-76.

E, S.Z., Yuan, J.C., Ding, Z.Y., Yao, F.J., Yu, X.P., and Luo, F.X. 2005. Effect of N, P, K fertilizer on Fe, Zn, Cu, Mn, Ca and Mg contents and yields in rice. Chinese Journal of Rice Science 19:434-440. 
GB7649-87. 1987. Pretreatment methods for determination of amino acids in cereal grains. Chinese Standard Press, Beijing, People's Republic of China.

GB/T 5009.90. 2003. Determination of iron, magnesium and manganese in foods. Chinese Standard Press, Beijing, People's Republic of China.

GB/T 5009.92. 2003. Determination of calcium in foods. Chinese Standard Press, Beijing, People's Republic of China.

Gong, J.L., Zhang, H.C., Long, H.Y., Hu, Y.J., Dai, Q.G., and Huo, Z.Y. 2012. Progress in research of nutrition functions and physiological mechanisms of silicon in rice. Plant Physiology Journal 48:1-10.

Grusak, M.A. 1994. Iron transport to developing ovules of Pisum sativum. Plant Physiology 104:649-655.

He, W.L., Shohag, M.J.I., Wei, Y.Y., Feng, Y., and Yang, X.E. 2013. Iron concentration, bioavailability, and nutritional quality of polished rice affected by different forms of foliar iron fertilizer. Food Chemistry 141:4122-4126.

Hossain, M.T., Mori, R., Soga, K., Wakabayashi, K., Kamisaka, S., Fujii, S., et al. 2002. Growth promotion and an increase in cell wall extensibility by silicon in rice and some other Poaceae seedlings. Journal of Plant Research 115:23-27.

Islam, A., and Saha, R.C. 1969. Effects of silicon on the chemical composition of rice plants. Plant and Soil 3:446-458.

Jiang, L.G., Cao, W.X., Gan, X.Q., Wei, S.Q., Xu, J.Y., Dong, D.F., et al. 2004. Relationship of nitrogen uptake and utilization to silicon nutrition in rice. Scientia Agricultura Sinica 37(5):648-655

Kim, Y.H., Khan, A.L., Waqas, M., Jeong, H.J., Kim, D.H., Shin, J.S., et al. 2014. Regulation of jasmonic biosynthesis by silicon application during physical injury to Oryza sativa L. Journal of Plant Research 127:525-532.

Liu, Q.H., Sun, Z.W., Xin, C.Y., and Ma, J.Q. 2016. Effects of silicon on dry matter remobilization, distribution and grain yield under high air temperature. Journal of Nuclear Agricultural Sciences 30(9):1833-1839.

Ma, J.F. 2004. Role of silicon in enhancing the resistance of plants to biotic and abiotic stresses. Soil Science and Plant Nutrition 50:11-18.

Meharg, C., and Meharg, A.A. 2015. Silicon, the silver bullet for mitigating biotic and abiotic stress, and improving grain quality, in rice? Environmental and Experimental Botany 120:8-17.

Miflim, B.J., and Habash, D.Z. 2002. The role of glutamate dehydrogenase in nitrogen assimilation and possibilities for improvement in the nitrogen utilization of crops. Journal of Experimental Botany 53:979-987.
Mitani, N., Ma, J.F., and Iwashita, T. 2005. Identification of silicon form in xylem sap of rice (Oryza sativa L.) Plant and Cell Physiology 46:279-283.

Nwugo, C.C., and Huerta, A.J. 2008. Effects of silicon nutrition on cadmium uptake, growth and photosynthesis of rice plants exposed to low-level cadmium. Plant and Soil 311:73-86.

Pati, S., Pal, B., Badole, S., Hazra, G.C., and Mandal, B. 2016. Effect of silicon fertilization on growth, yield, and nutrient uptake of rice. Communications in Soil Science and Plant Analysis 47(3):284-290.

Shan, Z.F. 2006. Mineral elements and human health. Studies of Trace Elements and Health 23:66-67.

Sperotto, R.A., Ricachenevsky, F.K., Waldow, V.A., and Fett, J.P. 2012. Iron biofortification in rice: It's a long way to the top. Plant Science 190:24-39.

Wang, H.M., Liu, Q.Q., and Gu, M.H. 2007. The nutritional quality of rice proteins and its genetic improvement. Plant Physiology Communications 43:391-396.

Wang, D.R., Lu, W.F., and Chen, W. 2001. Influence of nitrogen application on protein and amino acid contents in rice. Journal of Plant Nutrition and Fertilizer 7:353-356.

Wei, Y., Shohag, M., and Yang, X. 2012b. Biofortification and bioavailability of rice grain zinc as affected by different forms of foliar zinc fertilizer. PLoS ONE 7(9):e45428.

Wei, Y., Shohag, M., Yang, X., and Zhang, Y. 2012a. Effects of foliar iron application on iron concentration in polished rice grain and its bioavailability. Journal of Agriculture and Food Chemistry 60:11433-11439.

Xing, X.R., and Zhang, L. 1998. Review of the studies on silicon nutrition of plants. Chinese Bulletin of Botany 15:33-40.

Yamamoto, T., Nakamura, A., Iwai, H., Ishii, T., and Ma, J.F. 2012. Effect of silicon deficiency on secondary cell wall synthesis in rice leaf. Journal of Plant Research 125:771-779.

Yang, X.E., Ye, Z.Q., Shi, C.H., Zhu, M.L., and Graham, R.D. 1998. Genotypic differences in concentrations of iron, manganese, copper, and zinc in polished rice grains. Journal of Plant Nutrition 21:1453-1462.

Yuan, J.C., Liu, C.J., E, S.Z., Yang, S.M., Zhu, Q.S, and Yang, J.C. 2006. Effect of nitrogen application rate and fertilizer ratio on nutrition quality and trace-elements contents of rice grain. Journal of Plant Nutrition and Fertilizer 12:183-187.

Zhang, G.L., Dai, Q.G., Wang, J.W., Zhang, H.C., Huo, Z.Y., and Ling, L. 2007. Effect of silicon fertilizer rate on yield and quality of japonica rice Wuyujing 3. Chinese Journal of Rice Science 21:299-303. 